\title{
Fatal Hepatitis-Associated Aplastic Anemia in a Young Male
}

\author{
Dorotea Božić Ozretića Tonka Piplović Vukovića Jonatan Vukovića, b \\ Sanja Madunićc Kristian Podrug ${ }^{a}$ Željko Puljiz ${ }^{a, b}$ \\ aDepartment of Gastroenterology and Hepatology, University Hospital of Split, \\ Split, Croatia; ${ }^{b}$ University of Split, School of Medicine, Split, Croatia; 'Department of \\ Haematology, University Hospital of Split, Split, Croatia
}

\section{Keywords}

Hepatitis · Aplastic anemia $\cdot$ Hepatitis-associated aplastic anemia $\cdot$ Bone marrow transplantation · Deep neck infection

\begin{abstract}
Hepatitis-associated aplastic anemia is a rare syndrome in which bone marrow failure occurs within weeks to 1 year after attack of acute hepatitis. Studies suggest that cytotoxic T lymphocytes play a central role in bone marrow destruction, but the exact etiology remains unknown. Bone marrow transplantation or immunosuppressive therapy are primary curative options. We present a case of a young male who was admitted to the Department of Gastroenterology and Hepatology for acute hepatitis of an unknown cause. Liver biopsy revealed extensive inflammatory process with hepatocyte necrosis. Forty days later, new onset pancytopenia was identified. Bone marrow biopsy showed severe hypocellularity, and he was diagnosed with severe hepatitis-associated aplastic anemia. Treatment with cyclosporine was initiated, but with inadequate response, and pretransplant evaluation was started. Due to severe neutropenia, following alveotomy procedure, the patient developed deep neck infection with consequent airway obstruction. Despite urgent treatment, his condition deteriorated to sepsis with lethal outcome.




\section{Case Reports in Gastroenterology}

Case Rep Gastroenterol 2020;14:383-390

DOI: 10.1159/000508438

(c) 2020 The Author(s). Published by S. Karger AG, Basel www.karger.com/crg

Božić Ozretić et al.: Fatal Hepatitis-Associated Aplastic Anemia in a Young Male

\section{Background}

Hepatitis-associated aplastic anemia (HAAA) is a rare syndrome in which bone marrow (BM) failure occurs after an episode of acute hepatitis (AH). Hepatitis may be self-limiting, mild or severe, sometimes even fulminant, leading to urgent liver transplantation. HAAA accounts for 5\% of acquired aplastic anemias (AA), whose incidence in Europe is estimated to be 2-3 cases per million inhabitants per year [1-4]. It usually affects children and young males within weeks to one year after attack of $\mathrm{AH}$, frequently in the phase of liver function improvement [5]. The presumed cause of hepatitis is still unknown. HAAA is fatal if untreated, mostly due to serious bacterial infections, catalyzed by severe neutropenia.

\section{Case Presentation}

A 29-year-old male was admitted to the Department of Gastroenterology and Hepatology for acute liver injury. He was previously healthy, except for treatment for megaloblastic anemia for 2 years. Patient presented with malaise, headache, and muscle pain, with high transaminase and bilirubin levels (TBIL 324, AST 2,086, ALT 3,382), and coagulopathy (INR 1.42). He showed no signs of encephalopathy.

A wide spectrum of diagnostic procedures was conducted with exclusion of viral, autoimmune, and metabolic liver diseases. He reported drinking alcohol only on occasions and denied any illicit drug usage or exposure to any medications or toxins. Liver biopsy revealed an extensive inflammatory process involving both lobules and portal spaces with lytic and confluent hepatocyte necrosis, with no signs of fibrosis (Fig. 1). Corticosteroid treatment was initiated.

On day 41, new onset pancytopenia was identified (RBC $4.23 \times 10^{12} / \mathrm{L}, \mathrm{WBC} 2.99 \times 10^{9} / \mathrm{L}$, PLT $20 \times 10^{9} / \mathrm{L}$ ). At that time, his liver biochemical parameters showed persistent decrease and the corticosteroid treatment was continued (Fig. 2). On day 85, BM biopsy was performed and showed mild hypocellularity.

Since the pancytopenia progressed, BM biopsy was repeated on day 115 and revealed severe hypocellularity of $10 \%$, with no megakaryopoiesis (Fig. 3). BM immunophenotyping revealed dominance of T lymphocytes (77\%) with a high proportion of CD4 (31\%) and CD8 cells (41\%). Peripheral blood immunophenotyping also confirmed a high proportion of T cells (94\%), with the CD4/CD8 ratio on the lower limit (1.2). The cytogenetic study showed normal karyotype. Paroxysmal nocturnal hemoglobinuria clone was excluded. He met all criteria for the diagnosis of severe HAAA (BM cellularity 10\%, WBC $2.5 \times 10^{9} / \mathrm{L}$, Ne $0.40 \times 10^{9} / \mathrm{L}$, PLT 18 $\times 10^{9} / \mathrm{L}$, reticulocytes $16.7 \times 10^{9} / \mathrm{L}$ ). On the same day, treatment with cyclosporine (Cys) (2.5$3 \mathrm{mg} / \mathrm{kg}$ twice daily, adjusting trough levels to $200-400 \mathrm{ng} / \mathrm{mL}$ ) was initiated. He was immediately sent to the Bone Marrow Transplant Center, where it was decided to continue Cys treatment with regular assessment of the therapy response. He was further treated as an outpatient of both our Clinical Center and the Transplant Center, dependent on platelet transfusions two times a week. In that period, he was hospitalized several times for ulcerative gingivostomatitis, severe thrombocytopenia, febrile neutropenia, polyarthralgias, and maculopapular rash. Response on Cys treatment was inadequate, with persistent pancytopenia. Pretransplant evaluation for bone marrow transplantation (BMT) from a HLA-matched sibling (sister) was initiated.

Three months after initiation of Cys, he was admitted for febrile granulocytopenia and pain in the oral cavity due to gingival ulcerations. Microbiological analysis of throat swab 


\section{Case Reports in Gastroenterology}

Case Rep Gastroenterol 2020;14:383-390

DOI: $10.1159 / 000508438$

(c) 2020 The Author(s). Published by S. Karger AG, Basel www.karger.com/crg

Božić Ozretić et al.: Fatal Hepatitis-Associated Aplastic Anemia in a Young Male

revealed Enterococcus faecalis in low number of copies. He was treated with antibiotics, antifungal and antiviral prophylaxis, and adequate oral hygiene. Oral surgeon was consulted and alveotomy of the 8th teeth of mandible on the right side was performed because of impacted teeth with pericoronitis. The procedure went without complications. His condition began to improve, the inflammatory parameters decreased, and oral nutrition was introduced. Two weeks later, his clinical condition began to deteriorate again, with swelling and pain on the right side of the face. The suspicion on the peritonsillar abscess was raised, and the otorhinolaryngologist performed surgical incision and evacuation. Three days later, there was evident progression in the swelling of the face and neck, the patient was highly febrile, with swallowing and breathing difficulties.

Emergency MSCT revealed an abscess collection $4.2 \mathrm{~cm} \times 2.3 \mathrm{~cm}$ in the area of the retromolar trigone, with edema of oropharyngeal, parapharyngeal, and retropharyngeal soft tissues. Comprehensive edema of subcutaneous soft tissues of neck with the thickening of platysma was also described (Fig. 4). Urgent tracheotomy with neck incision and evacuation was performed. His treatment with wide spectrum antibiotics, antifungals, granulocyte stimulating factors, and transfusions of platelets and erythrocytes was continued. Despite all measures he died due to sepsis with development of disseminated intravascular coagulation, 4 months after the diagnosis of HAAA.

\section{Discussion}

Severe AA is defined according to the Camitta criteria: BM cellularity $<25 \%$ together with two of the following criteria: neutrophils $<0.5 \times 10^{9} / \mathrm{L}$, platelets $<20 \times 10^{9} / \mathrm{L}$, and reticulocytes $<20 \times 10^{9} / \mathrm{L}[6]$.

HAAA is a rare form of AA, occurring after attack of AH. Although it may follow viral infections such as HIV, hepatitis A, B, C, G, EBV, CMV, parvo B19, echovirus, and transfusion transmitted virus, the majority of cases are seronegative for hepatotropic viruses $[1,5,7,8]$. Studies report a viral etiology in only $6 \%$ of cases [1]. HAAA was also described in connection with toxic liver injury [9] and is reported in patients who underwent orthotopic liver transplantation for nonviral hepatitis [10]. Our patient developed severe AA after an episode of seronegative $\mathrm{AH}$, in the phase of liver function improvement.

According to the immunopathogenesis of HAAA, studies suggest an antigen-driven T cell expansion, with the initial target organ being the liver [11]. Infiltration of clonal and nonclonal $\mathrm{T}$ cells, presenting as skewed $\mathrm{T}$ cell repertoire, occurs both in liver and in the blood at the time of BM failure [11]. Common cytotoxic T lymphocytes (CTL) recognize similar target antigens in BM cells as in liver in the early period, and then selective clonal expansion of CTL that are highly tropic to BM occurs, with subsequent destruction of BM cells at later stages [12]. CTL produce IFN- $\gamma$, which itself and by activation of cytokine cascade leads to cell apoptosis and necrosis, ultimately inhibiting hematopoiesis [7]. This is confirmed by immunohistochemical staining of liver specimens, revealing accumulation of CTL in HAAA patients, as well as increased proportion of HLA DR-positive CD8 cells (which are considered to be activated CTL) and decreased CD4/CD8 ratio in their peripheral blood [5, 7, 13]. CD8-expressing Kupffer cells may be important mediators of HAAA [14]. Response to immunosuppressive therapy (IST) has been proven by replacement of broad skewing pattern of $\mathrm{T}$ cell distribution to normal [11, 12]. Our patient had plentiful T lymphocyte infiltrate both in liver and BM specimen, as well as in peripheral blood, with low normal CD4/CD8 ratio. 


\section{Case Reports in Gastroenterology}

Case Rep Gastroenterol 2020;14:383-390

DOI: $10.1159 / 000508438$

(c) 2020 The Author(s). Published by S. Karger AG, Basel www.karger.com/crg

Božić Ozretić et al.: Fatal Hepatitis-Associated Aplastic Anemia in a Young Male

HAAA is always fatal without treatment. The first-line therapy is allogenic BMT from an HLA-matched sibling [7]. According to studies, the mean survival after BMT is $82-86 \%$ at 5 years and $70 \%$ at 10 years $[1,7,15]$. IST is reserved for patients without an HLA-matched sibling donor and includes antithymocyte globulin (ATG), antilymphocyte globulin, Cys, and cyclophosphamide [5, 16-18]. Combination of Cys and ATG together with growth factors is the treatment of choice. The mean response rate with intensive combined IST is $70-80 \%$ [5, $17,18]$, with predicted 10 -year survival of $69-88 \%[1,18]$. According to Locasciulli et al. [1], the strongest negative predictors of survival are age over 20 years and delayed treatment. Patients with very severe HAAA $\left(<0.2 \times 10^{9} / \mathrm{L}\right)$ take longer to respond to therapy [18]. It is recommended not to delay IST despite potential hepatotoxic effects of Cys and ATG, which may even improve liver function by suppression of T lymphocytes [7, 18]. For patients not responding on IST, BMT from HLA-matched unrelated donor is an option [1, 7]. Prophylactic therapy for CMV is recommended due to risk of interstitial pneumonitis [18]. In HBsAg- or anti-HBc-positive patients, antiviral prophylaxis with lamivudine, telbivudine, or entecavir is advocated [7]. The most common causes of death are severe infections and intracranial hemorrhage $[13,15,18]$.

The treatment of our patient was started with Cys due to severe HAAA at the time of diagnosis. He was immediately sent to the Bone Marrow Transplant Center, where it was decided to continue Cys and to consider other treatment options depending on the response. Three months later, at the time when the pretransplant evaluation of our patient and the donor was ongoing, he was admitted for febrile neutropenia. He developed retromolar trigone abscess with the infection spreading to deep neck tissues, leading to airway obstruction. Deep neck infections (DNI) are defined as infections in the potential spaces and the fascial planes of the neck [19]. Odontogenic infections are the most common cause of DNI, responsible for $70 \%$ of cases in adults, and it is assumed that the port of entry in our patient was the dental procedure performed 2 weeks earlier [20]. Risk factors for DNI development are immunosuppression, low socioeconomic status, and comorbidities, while the main isolated pathogens are Staphylococci, Streptococci, and Enterococci species [20]. Most frequent complications are airway obstruction, descending necrotizing mediastinitis, Lemierre's syndrome, necrotizing cervical fasciitis, pneumonia, and sepsis $[19,20]$. Treatment with broad-spectrum antibiotics is obligatory, usually in combination with surgical treatment $[19,20]$. Despite both surgical and antibiotic treatment with supportive measures that were taken in our patient, his condition deteriorated and led to lethal outcome.

In conclusion, when treating patients with $\mathrm{AH}$, one must always consider the possibility of HAAA development, usually in the phase of liver function improvement. Delayed diagnosis and treatment are significant negative predictors of survival. BMT, or IST in patients without HLA-matched sibling donor, are the cornerstones of treatment. Since patients with AA are highly susceptible to infections, special caution is recommended regarding odontogenic infections that may lead to DNI and cause life-threatening complications such as airway obstruction, necrotizing mediastinitis, or sepsis. Thorough dental and periodontal care with antibiotic and antiviral prophylaxis in patients with AA is of great importance. 


\section{Case Reports in Gastroenterology} \begin{tabular}{l|l}
\hline DOI: 10.1159/000508438 & $\begin{array}{l}\text { (c) 2020 The Author(s). Published by S. Karger AG, Basel } \\
\text { www.karger.com/crg }\end{array}$
\end{tabular}

Božić Ozretić et al.: Fatal Hepatitis-Associated Aplastic Anemia in a Young Male

\section{Statement of Ethics}

The research was conducted ethically in accordance with the World Medical Association Declaration of Helsinki. We obtained approval and written informed consent for participation and publication from the family member. The consent form is available if requested from the Editor.

\section{Conflict of Interest Statement}

The authors have no conflicts of interest to declare.

\section{Funding Sources}

The authors have funded all research personally.

\section{Author Contributions}

D.B.O., T.P.V., and Ž.P. designed the report; K.P., T.P.V., and S.M. treated the patient; D.B.O. collected the patient's data; D.B.O., K.P., S.M., and T.P.V. analyzed the data, D.B.O. and J.V. wrote the paper. All the authors gave their approval for the final version of the article to be published and all the authors agreed to be accountable for all aspects of the work in ensuring that questions related to the accuracy or integrity of any part of the work are appropriately investigated and resolved.

\section{References}

1 Locasciulli A, Bacigalupo A, Bruno B, Montante B, Marsh J, Tichelli A, et al.; Severe Aplastic Anemia Working Party of the European Blood and Marrow Transplant Group (SAA-WP, EBMT). Hepatitis-associated aplastic anaemia: epidemiology and treatment results obtained in Europe. A report of The EBMT aplastic anaemia working party. Br J Haematol. 2010 Jun;149(6):890-5.

2 Vaht K, Göransson M, Carlson K, Isaksson C, Lenhoff S, Sandstedt A, et al. Incidence and outcome of acquired aplastic anemia: real-world data from patients diagnosed in Sweden from 2000-2011. Haematologica. 2017 Oct;102(10):1683-90.

3 International Agranulocytosis and Aplastic Anemia Study. Incidence of aplastic anemia: the relevance of diagnostic criteria. Blood. 1987;70(6):1718-21.

4 Montané E, Ibáñez L, Vidal X, Ballarín E, Puig R, García N, et al.; Catalan Group for Study of Agranulocytosis and Aplastic Anemia. Epidemiology of aplastic anemia: a prospective multicenter study. Haematologica. 2008 Apr;93(4):518-23.

5 Brown KE, Tisdale J, Barrett AJ, Dunbar CE, Young NS. Hepatitis-associated aplastic anemia. N Engl J Med. 1997 Apr;336(15):1059-64.

6 Camitta BM, Rappeport JM, Parkman R, Nathan DG. Selection of patients for bone marrow transplantation in severe aplastic anemia. Blood. 1975 Mar;45(3):355-63.

7 Gonzalez-Casas R, Garcia-Buey L, Jones EA, Gisbert JP, Moreno-Otero R. Systematic review: hepatitisassociated aplastic anaemia - a syndrome associated with abnormal immunological function. Aliment Pharmacol Ther. 2009 Sep;30(5):436-43.

8 Rauff B, Idrees M, Shah SA, Butt S, Butt AM, Ali L, et al. Hepatitis associated aplastic anemia: a review. Virol J. $2011 \mathrm{Feb} ; 8(1): 87$.

9 Qureshi K, Sarwar U, Khallafi H. Severe Aplastic Anemia following Acute Hepatitis from Toxic Liver Injury: Literature Review and Case Report of a Successful Outcome. Case Reports Hepatol. 2014;2014:216570. 


\section{Case Reports in Gastroenterology}

\begin{tabular}{l|l}
\hline DOI: 10.1159/000508438 & $\begin{array}{l}\text { @ } 2020 \text { The Author(s). Published by S. Karger AG, Basel } \\
\text { www.karger.com/crg }\end{array}$ \\
\hline
\end{tabular}
www.karger.com/crg

Božić Ozretić et al.: Fatal Hepatitis-Associated Aplastic Anemia in a Young Male

10 Delehaye F, Habes D, Dourthe ME, Bertrand Y, Michel G, Gaudichon J, et al. Management of childhood aplastic anemia following liver transplantation for nonviral hepatitis: a French survey. Pediatr Blood Cancer. 2020 Apr;67(4):e28177.

11 Lu J, Basu A, Melenhorst JJ, Young NS, Brown KE. Analysis of T-cell repertoire in hepatitis-associated aplastic anemia. Blood. 2004 Jun;103(12):4588-93.

12 Ikawa Y, Nishimura R, Kuroda R, Mase S, Araki R, Maeba H, et al. Expansion of a liver-infiltrating cytotoxic Tlymphocyte clone in concert with the development of hepatitis-associated aplastic anemia. Br J Haematol. 2013;161(4):599-602.

13 Wang H, Tu M, Fu R, Wu Y, Liu H, Xing L, et al. The clinical and immune characteristics of patients with hepatitis-associated aplastic anemia in China. PLoS One. 2014 May;9(5):e98142-7.

14 Cengiz C, Turhan N, Yolcu OF, Yilmaz S. Hepatitis associated with aplastic anemia: do CD8(+) kupffer cells have a role in the pathogenesis? Dig Dis Sci. 2007 Sep;52(9):2438-43.

15 Mori T, Onishi Y, Ozawa Y, Kato C, Kai T, Kanda Y, et al. Outcome of allogeneic hematopoietic stem cell transplantation in adult patients with hepatitis-associated aplastic anemia. Int J Hematol. 2019 Jun;109(6):711-7.

16 Savage WJ, DeRusso PA, Resar LM, Chen AR, Higman MA, Loeb DM, et al. Treatment of hepatitis-associated aplastic anemia with high-dose cyclophosphamide. Pediatr Blood Cancer. 2007 Dec;49(7):947-51.

17 Chen HF, Xu BX, Shen HS, Li ZY, Jin LJ, Tang JQ, et al. Efficacy and safety of immunosuppressive therapy in the treatment of seronegative hepatitis associated aplastic anemia. Drug Des Devel Ther. 2014 Sep;8:1299-305.

18 Osugi Y, Yagasaki H, Sako M, Kosaka Y, Taga T, Ito T, et al.; Japan Childhood Aplastic Anemia Study Group. Antithymocyte globulin and cyclosporine for treatment of 44 children with hepatitis associated aplastic anemia. Haematologica. 2007 Dec;92(12):1687-90.

19 Kauffmann P, Cordesmeyer R, Tröltzsch M, Sömmer C, Laskawi R. Deep neck infections: a single-center analysis of 63 cases. Med Oral Patol Oral Cir Bucal. 2017 Sep;22(5):e536-41.

20 Adoviča A, Veidere L, Ronis M, Sumeraga G. Deep neck infections: review of 263 cases. Otolaryngol Pol. 2017 Oct;71(5):37-42.

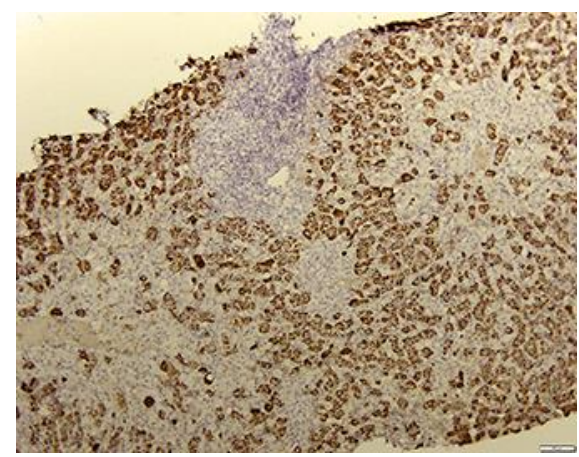

Fig. 1. Liver biopsy specimen (HSA immunohistochemical staining): acute lobular and portal Tymphocyte infiltrate with lytic and confluent hepatocyte necrosis. 
Case Reports in Gastroenterology
Case Rep Gastroenterol 2020;14:383-390

DOI: $10.1159 / 000508438$

(c) 2020 The Author(s). Published by S. Karger AG, Basel www.karger.com/crg

Božić Ozretić et al.: Fatal Hepatitis-Associated Aplastic Anemia in a Young Male
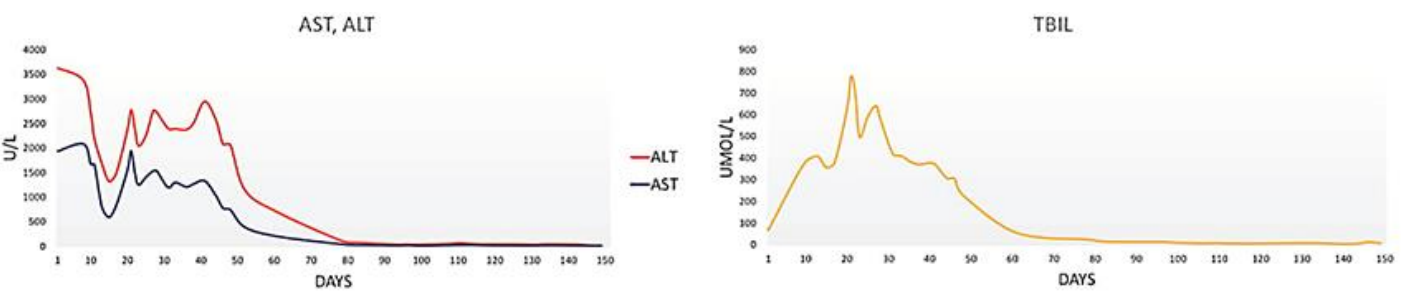

WBC
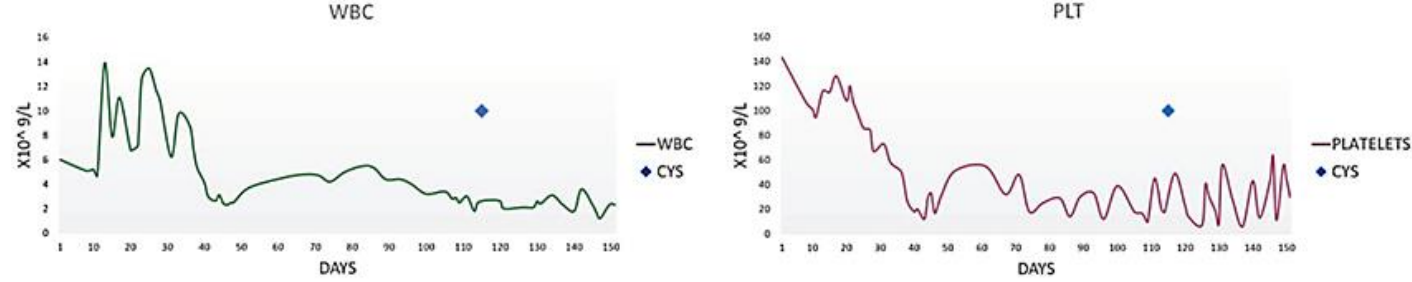

Fig. 2. Graphical trends of the laboratory parameters in the first 5 months after admission. AST, aspartate transaminase; ALT, alanine transaminase; TBIL, total bilirubin; CYS, cyclosporine introduction; WBC, white blood cell count; PLT, platelets.

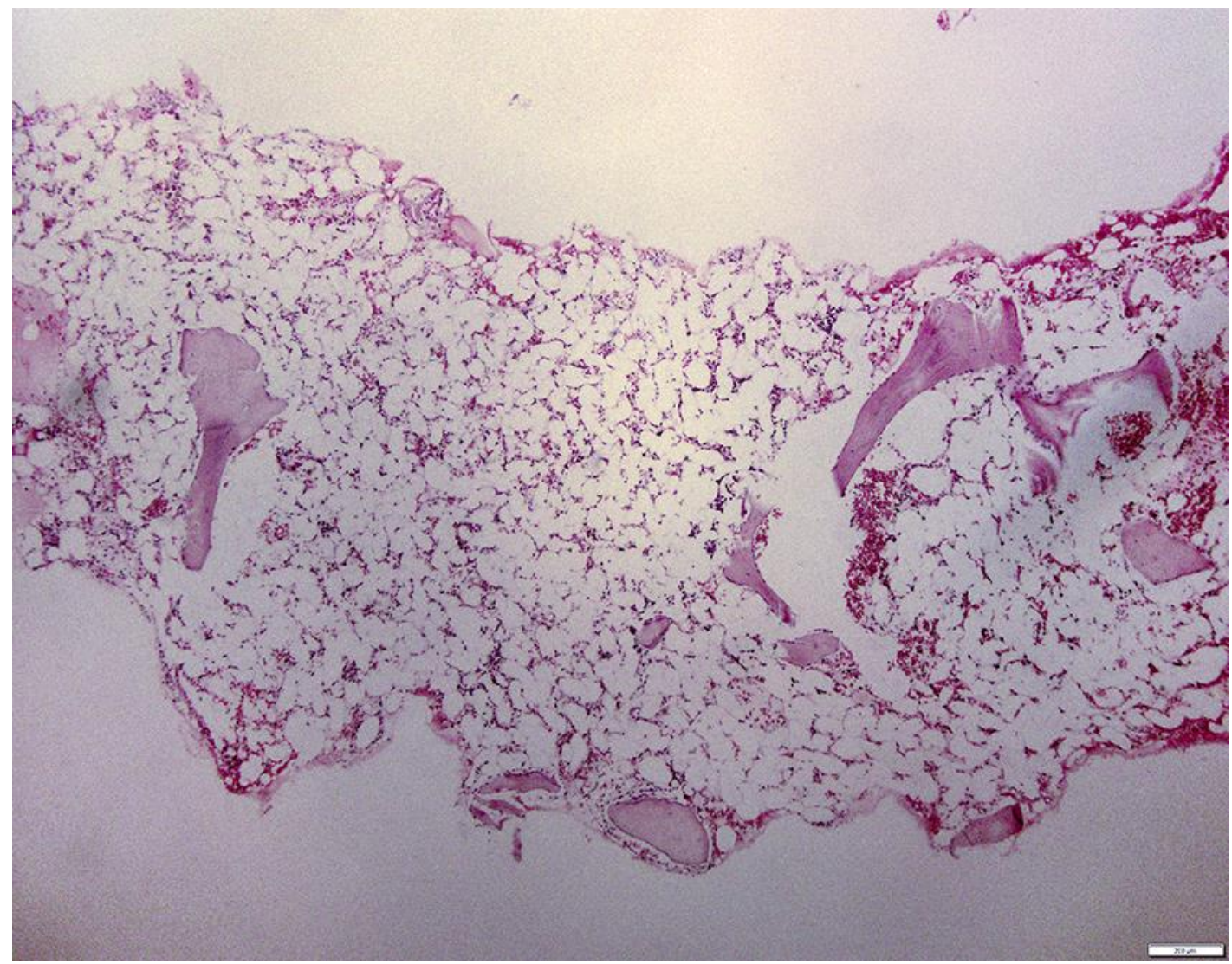

Fig. 3. Bone marrow specimen: very low cellularity with partial acellularity. 
Case Reports in Gastroenterology
Case Rep Gastroenterol 2020;14:383-390

DOI: $10.1159 / 000508438$

(c) 2020 The Author(s). Published by S. Karger AG, Basel www.karger.com/crg

Božić Ozretić et al.: Fatal Hepatitis-Associated Aplastic Anemia in a Young Male

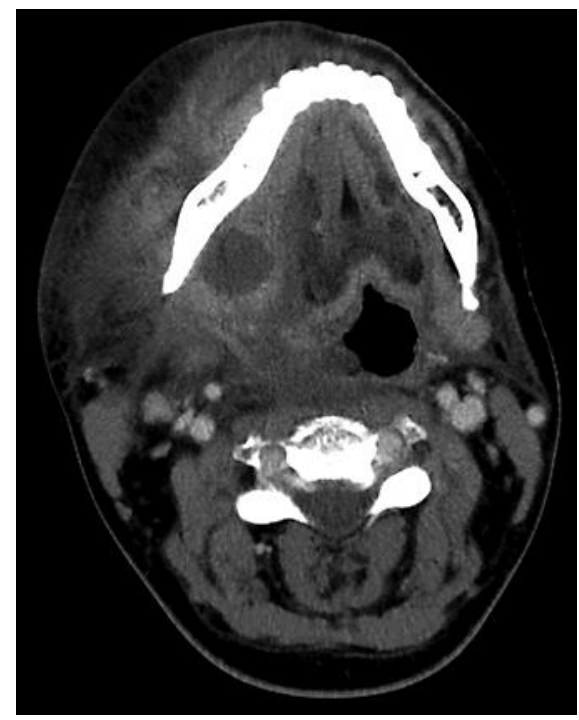

Fig. 4. MSCT of the neck: an abscess collection in the area of the retromolar trigone, with edema of deep neck tissues. 